\title{
APPARENT AGES OF MARINE SHELLS: IMPLICATIONS FOR ARCHAEOLOGICAL DATING IN HAWAI'I
}

\section{TOM DYE}

\author{
State of Hawai'i, Department of Land and Natural Resources, Historic Preservation Division \\ P.O. Box 621, Honolulu, Hawai'i 96809
}

\begin{abstract}
The conventional ${ }^{14} \mathrm{C}$ ages of 8 marine shells of known age and 11 marine shells stratigraphically associated with dated wood charcoal show considerable variation from expected ages. One source of this variation is seashore geology; comparison of 6 AMS dates on 3 species of shallow-water, herbivorous gastropod shells from Pleistocene limestone and Holocene volcanic coasts shows that shells from Pleistocene limestone coasts can have apparent, or reservoir, ${ }^{14} \mathrm{C}$ ages up to $620 \mathrm{yr}$ greater than shells of the same species from volcanic coasts. The relatively great variation in apparent ages of Hawaiian marine shells poses problems for their use in dating archaeological sites. For best results, an archaeological marine shell should be sourced to a particular local environment, and the apparent age of shells in that environment determined by dating well-provenienced shells of known age.
\end{abstract}

\section{INTRODUCTION}

Hawai' $i$ was discovered and settled sometime in the first millennium $\mathrm{AD}, \mathrm{ca} .1000 \mathrm{yr}$ before the written observations of Cook and his crew brought the islands' prehistory to an end. The brevity of Hawaii's prehistoric period is appealing to those prehistorians who are interested in dating relatively short-term processes. In such a case, accurate calibration of radiocarbon dates is essential. Marine shells often offer substantial contextual advantages over wood charcoal for dating human activity at Hawaiian archaeological sites (Beggerly 1990). Despite these advantages, few marine shells have been dated because modest variation in their apparent ages, if not identified and corrected, could make these dates unreliable.

Calibration of marine shell ${ }^{14} \mathrm{C}$ dates is based on a model history of ${ }^{14} \mathrm{C}$ variations in the surface layers of the world ocean (Stuiver, Pearson and Braziunas 1986; Stuiver and Braziunas 1993). Regional deviations from this model are denoted by a factor, $\Delta R$, which can be calculated from the conventional ${ }^{14} \mathrm{C}$ age of marine shells of known, pre-atomic-era calendar age, or estimated from the difference in age between stratigraphically paired samples of marine shell and a material, such as wood charcoal, from the terrestrial biosphere. Stuiver, Pearson, and Braziunas (1986) reported a $\Delta R$ value of $117 \pm 50$ for the Hawaiian islands from the conventional ${ }^{14} \mathrm{C}$ age of 1 of 2 Trochus intextus Kiener shells dated and identified incorrectly as Trechus intertextus by Broecker and Olson (1961). A second T. intextus shell, collected in 1936 at Pearl Harbor, O'ahu, yielded an unexpectedly old conventional ${ }^{14} \mathrm{C}$ age of $4300 \pm 100$ (Broecker and Olson 1961). Broecker and Olson advanced two hypotheses to explain the apparent age of the shell, which is clearly an outlier. Pollution of Pearl Harbor with fossil fuels during its use as a naval base in this century might also explain the questionable nature of this sample, which is unlikely to provide useful information on natural variability in the apparent ages of Hawaiian marine shells.

\section{VARIABILITY IN APPARENT AGES OF DATED MARINE SHELLS OF KNOWN AGE}

The ${ }^{14} \mathrm{C}$ ages of six other marine shells of known age show considerable variation from expected ages (Table 1). Athens (1985) and Beggerly (1990) dated marine shells from several locations on O'ahu Island and the south shore of Moloka'i Island, including three specimens of Tellina (Quidnipagus) palatam Iredale, a filter-feeding bivalve found in silty sands at 2-3 m depth (Kay 1979). The habitat and eating behavior of $T$. palatam suggest that it takes most of its carbon from the general ocean reservoir. $\Delta \mathrm{R}$ values calculated from the ${ }^{14} \mathrm{C}$ ages of the $T$. palatam shells vary between 210 \pm 40 and $-60 \pm 60$, with a weighted mean of $60 \pm 90$, where the error term is the "scatter" sigma of 
the unweighted mean following Stuiver, Pearson and Braziunas (1986:982). The scatter sigma is used here because it potentially incorporates all sources of uncertainty in the error term, unlike the sigma calculated from errors in the ${ }^{14} \mathrm{C}$ ages, which incorporates only laboratory uncertainties.

The ${ }^{14} \mathrm{C}$ ages of other shell species vary widely from $T$. palatam. Beggerly (1990) dated a Macoma (Cissulina) dispar (Conrad) shell, a close relative of $T$. palatam found more often in areas with significant freshwater discharge (Kay 1979), and two Conus distans Hwass, a carnivorous gastropod that feeds on polychaete worms (Kay 1979). The $M$. dispar shell was more active than the modern standard, yielding a $\Delta \mathrm{R}$ of $-500 \pm 120$. The two $C$. distans shells, collected just a few miles from each other on the windward coast of $O$ 'ahu Island, yielded $\Delta R$ values $>400$ yr apart. No hypotheses have been advanced to account for the extreme variability in the apparent ages of these shells.

TABLE 1. Conventional Dates on Marine Shells of Known Age

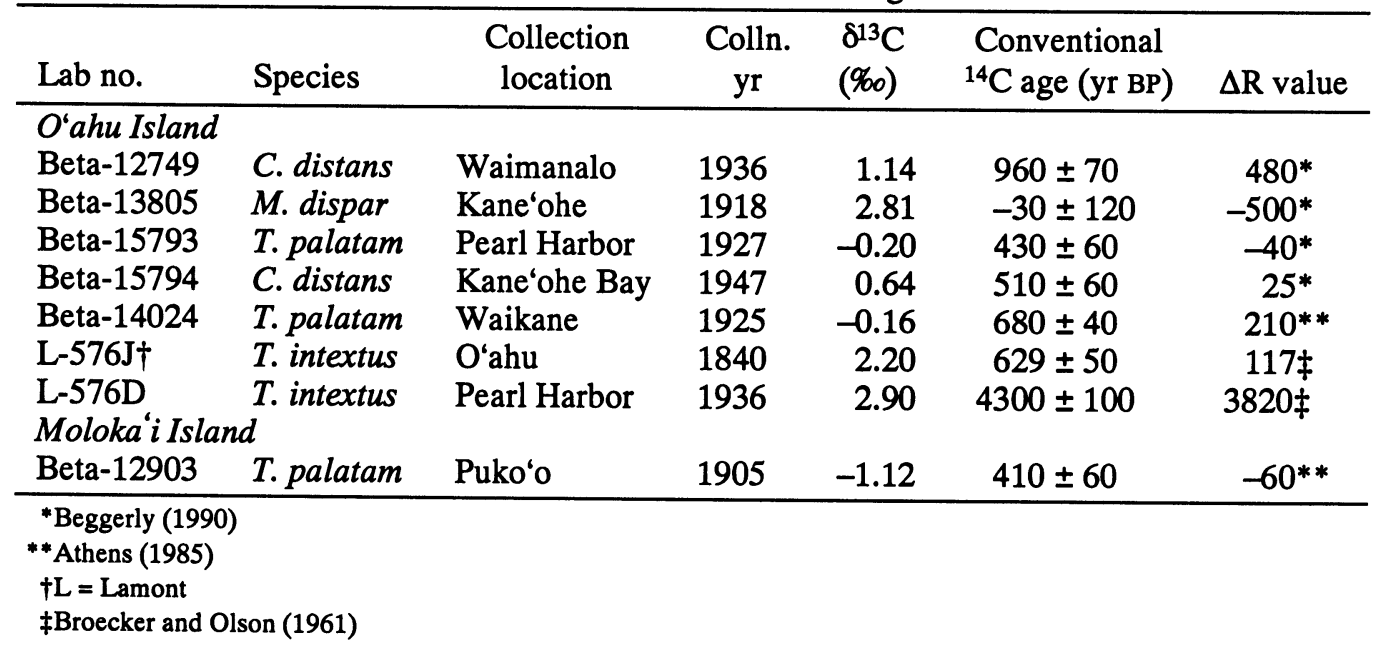

\section{MARINE SHELLS STRATIGRAPHICALLY ASSOCIATED WITH DATED WOOD CHARCOAL}

In the 1950 s and early 1960 s, as part of an investigation into the suitability of various archaeological materials for ${ }^{14} \mathrm{C}$ dating, R. M. Chatters, of the Radioisotopes and Radiation Laboratory at Washington State University, dated seven paired Cypraea spp. and charcoal samples from successive 3.8- and 7.6-cm levels of a single excavation unit at the H8 site at South Point, Hawai'i Island (Emory and Sinoto 1969). The shells were presumably brought to the site from the nearby coast, which consists of Holocene lavas $>4000$ to a few hundred yr old (Lockwood et al. 1988), and is similar to coasts for many kilometers in either direction.

The methods used $>30 \mathrm{yr}$ ago to collect and date the charcoal and shell samples fall short of modern standards, and increase the uncertainty in estimates of the apparent ages of the shells. These shortcomings include: 1) the excavation method, which proceeded by arbitrary levels without control for intrusive features, does not guarantee the stratigraphic association of the paired samples; 2) no record was kept to indicate which of the 34 species in the Hawaiian genus, Cypraea, was dated; because habitat and feeding behavior vary widely among species (Kay 1979) interspecific variation in apparent age may occur; and 3) the ${ }^{14} \mathrm{C}$ ages of both the charcoal and shell samples were not corrected for isotopic fractionation. The effects of the first two sources of uncertainty cannot be esti- 
mated with confidence, but the latter can, and the ${ }^{14} \mathrm{C}$ ages of the shell samples have been recalculated under the assumption that $\delta^{13} \mathrm{C}=0.0 \%$ (Taylor 1987).

Four of the 7 paired ${ }^{14} \mathrm{C}$ ages show a reasonably consistent relation, with Cypraea spp. ${ }^{14} \mathrm{C}$ ages between 350 and $545{ }^{14} \mathrm{C}$ yr older than those from wood charcoal (Table 2). The three other pairs yielded widely discrepant results. The WSU-489/WSU-514 pair inverts the usual relation, with a wood charcoal ${ }^{14} \mathrm{C}$ age $75 \mathrm{yr}$ older than that from Cypraea sp. shell. The WSU-480/WSU-549 and WSU-478/WSU-558 pairs yielded large differences, apparently due to problems with the ${ }^{14} \mathrm{C}$ ages of the wood charcoal. Wood charcoal sample, WSU-480, yielded a future age, and WSU-478, from the base of the stratigraphic column, yielded a younger age than the five wood charcoal samples overlying it. Excluding the WSU-480/WSU-549 pair, with its obviously anomalous future wood charcoal ${ }^{14} \mathrm{C}$ age, the unweighted mean difference of the six pairs is $540 \pm 210$. If the WSU-489/ WSU-514 and WSU-478/WSU-558 pairs are also excluded, the unweighted mean difference of the four remaining pairs is $450 \pm 40$, with the error term calculated as above. Weighted-mean $\Delta R$ estimates of $210 \pm 200$ for the 6 pairs and $70 \pm 30$ for the 4 pairs are derived following a procedure detailed by Stuiver and Braziunas (1993).

TABLE 2. Comparison of Charcoal and Cypraea Spp. Shell ${ }^{14} \mathrm{C}$ Age Determinations on Samples of Presumed Similar Age from Archaeological Site H8, Wai'ahukini, Hawai'i*

\begin{tabular}{llrcc}
\hline Lab no. & Material & $\begin{array}{c}{ }^{14} \mathrm{C} \text { age** } \\
\text { (yr BP) }\end{array}$ & $\begin{array}{c}\text { Apparent } \\
{ }^{*} \mathrm{C} \text { age }(\mathrm{yr})\end{array}$ & $\begin{array}{c}\Delta \mathrm{R} \\
\text { value }\end{array}$ \\
\hline WSU-480† & Charcoal & $-1400 \pm 300$ & -- & \\
WSU-549 & Shell & $1380 \pm 220$ & 2780 & -- \\
WSU-479 & Charcoal & $685 \pm 300$ & -- & \\
WSU-548 & Shell & $1230 \pm 180$ & 545 & 120 \\
WSU-486 & Charcoal & $965 \pm 310$ & -- & \\
WSU-551 & Shell & $1460 \pm 150$ & 495 & 80 \\
WSU-487 & Charcoal & $1195 \pm 210$ & -- & \\
WSU-544 & Shell & $1610 \pm 160$ & 415 & 60 \\
WSU-488 & Charcoal & $1100 \pm 140$ & -- & \\
WSU-513 & Shell & $1450 \pm 310$ & 350 & -10 \\
WSU-489 & Charcoal & $1185 \pm 320$ & -- & \\
WSU-514 & Shell & $1110 \pm 300$ & -75 & -440 \\
WSU-478 & Charcoal & $400 \pm 160$ & -- & \\
WSU-558 & Shell & $1900 \pm 160$ & 1500 & 1040 \\
\hline
\end{tabular}

*Source: Emory and Sinoto (1969)

$* * \delta^{13} \mathrm{C}=0.0 \%$ assumed for shell samples; $-25.0 \%$ assumed for charcoal samples +WSU = Washington State University

Four stratigraphically paired marine shell and charcoal dates from archaeological sites at Barbers Point, O'ahu (Davis 1990) yield estimates of $\Delta R$ that are significantly different from the values derived from shells of known age (Table 1) and estimated from the H8 site Cypraea spp. shells (Table 2). Barbers Point is located on the 'Ewa Coral Plain, an emerged Pleistocene reef that forms the coastal lowlands of southwestern O'ahu (Macdonald and Abbott 1970). Present-day freshwater discharge along most of this arid coast is primarily the result of sugar cane plantation irrigation 
water added to the caprock aquifer (Stearns and Vaksvik 1935). Before the establishment of plantations on the 'Ewa Plain at the end of the last century, the aquifer would have been "supplied by losses from ephemeral streams . . . and by direct penetration of rainfall" (Stearns and Vaksvik 1935:227). Seawater circulates freely along this coast because the well-developed fringing reef is narrow, exposing the shoreline to wave action.

Davis (1990) dated Nerita picea Recluz, a small gastropod that browses algae between the splash zone and the high water mark (Kay 1979). N. picea is common along rocky coasts throughout Hawai' $i$, including Barbers Point, and it is one of the most common shell species found as food refuse in archaeological sites. There is no reason to believe that the shells dated by Davis were brought into the site from a volcanic coast, the closest of which is $>8 \mathrm{~km}$ away. Stratigraphic contemporaneity for 3 of the 4 paired samples was assured by selecting shell and wood charcoal pairs from the same hearth feature. The fourth pair (Beta-9058/Beta-11715) is from the same living floor; the charcoal sample is from a hearth feature and the $N$. picea shells are from a small concentration of shells located 3-4 m from the hearth (Davis 1990). Conventional ${ }^{14} \mathrm{C}$ ages are available for the wood charcoal samples, but not for the $N$. picea samples. If a $\delta^{13} \mathrm{C}$ value of $0.0 \%$ is assumed for the marine shells, as above, then their ${ }^{14} \mathrm{C}$ ages are $1030-1740$ yr greater than the paired wood charcoal samples (Table 3). A weighted-mean $\Delta R$ value of $990 \pm 145$ differs significantly from the $\Delta R$ values derived from the $T$. palatam shells of known age and the paired wood charcoal and Cypraea spp. shells from the $\mathrm{H} 8$ site.

TABLE 3. Comparison of Charcoal and Nerita Picea Shell ${ }^{14} \mathrm{C}$ Determinations on Samples of Presumed Similar Age from Archaeological Sites at Barbers Point, O'ahu*

\begin{tabular}{llrcc}
\hline Lab no. & Material & \multicolumn{1}{c}{$\begin{array}{c}{ }^{14} \mathrm{C} \text { age** } \\
\text { (yr BP) }\end{array}$} & $\begin{array}{c}\text { Apparent } \\
{ }^{14} \text { C age (yr) }\end{array}$ & $\begin{array}{c}\Delta R \\
\text { value }\end{array}$ \\
\hline Beta-9543 & Charcoal & $400 \pm 70$ & -- & \\
Beta-9547 & Shell & $1870 \pm 60$ & 1470 & 1000 \\
Beta-9052 & Charcoal & $550 \pm 50$ & -- & \\
Beta-9059 & Shell & $1580 \pm 90$ & 1030 & 600 \\
Beta-9057 & Charcoal & $270 \pm 50$ & -- & \\
Beta-9549 & Shell & $2010 \pm 70$ & 1740 & 1310 \\
Beta-9058 & Charcoal & $220 \pm 70$ & -- & \\
Beta-11715 & Shell & $1630 \pm 60$ & 1410 & 970 \\
\hline *Source: Davis (1990: 318-319) & & & \\
${ }^{* *}$ O $^{13} \mathrm{C}=0.0 \%$ assumed for shell samples & & &
\end{tabular}

\section{EFFECTS OF PLEISTOCENE LIMESTONE SUBSTRATE ON THE APPARENT AGES OF GASTROPOD SHELLS}

Six marine shells of known, pre-atomic-era age were dated by Beta Analytic and Lawrence Livermore Laboratory, using accelerator mass spectrometry (AMS) to test the effects of Pleistocene limestone substrate on the apparent ages of three species of shell that are commonly recovered from archaeological sites-N. picea, Cypraea caputserpentis Linnaeus and Cellana exarata (Reeve). The limpet, $C$. exarata, grazes the intertidal and splash zones, particulary on volcanic substrates, and often occurs with $N$. picea. $C$. caputserpentis is largely herbivorous and is found from the shallow water at the shoreline to the edge of fringing reefs (Kay 1979). 
I selected shells for dating from two coastlines, one dominated by Pleistocene limestone and the other by Holocene lavas. C. caputserpentis and C. exarata shells collected at Kaulana in 1923 are from Holocene lavas $>4000 \mathrm{yr}$ old (Lockwood et al. 1988). $N$. picea shells collected in 1924 at "Kea'au," a town ca. $6 \mathrm{~km}$ inland, probably derive from the adjacent coast, where lava flows range in age from 350 to $>4000 \mathrm{yr}$ (Holcomb 1987). The apparent ${ }^{14} \mathrm{C}$ ages of these shells should approximate the estimates derived from the H8 site Cypraea spp. shells (Table 2). C. caputserpentis and $C$. exarata shells collected at Barbers Point in 1914 and 1915, and N. picea shells collected at Kualakai are all from coasts that are composed primarily of Pleistocene limestones of the 'Ewa Coral Plain. The apparent ${ }^{14} \mathrm{C}$ ages of these shells should approximate the estimates derived from the archaeological N. picea shells from Barbers Point (Table 3).

Marine shells from volcanic coasts yield $\Delta R$ values between $140 \pm 80$ and $270 \pm 100$ (Table 4), whereas those from the Pleistocene limestone coast yield $\Delta R$ values between $510 \pm 80$ and $800 \pm$ 80. Variance in $\Delta R$ between the two types of coast is greater than interspecific variance in shells from either coast. Intraspecific differences in shells from the two types of coasts are greatest in the two species that graze the intertidal and splash zones. $C$. exarata collected from Pleistocene limestone yields an apparent ${ }^{14} \mathrm{C}$ age $530 \mathrm{yr}$ older than shells from a lava coast. The difference in $N$. picea shells is $620 \mathrm{yr}$. In contrast, $C$. caputserpentis shells collected from shallow offshore waters differ by only $250 \mathrm{yr}$.

TABLE 4. AMS Dates on Marine Shells from Pleistocene Limestone and Holocene Volcanic Coasts

\begin{tabular}{lllccc}
\hline Lab no. & Species & Substrate & $\begin{array}{c}\text { Colln. } \\
\mathrm{yr}\end{array}$ & $\begin{array}{c}\text { Convent. } \\
{ }^{14} \mathrm{C} \text { age }\end{array}$ & $\begin{array}{c}\Delta \mathrm{R} \\
\text { value }\end{array}$ \\
\hline Beta-54332 & C. exarata & Limestone & 1914 & $1270 \pm 80$ & 800 \\
Beta-54336 & C. exarata & Volcanic & 1923 & $740 \pm 100$ & 270 \\
Beta-54331 & C. caputserpentis & Limestone & 1915 & $980 \pm 80$ & 510 \\
Beta-54334 & C. caputserpentis & Volcanic & 1923 & $730 \pm 80$ & 260 \\
Beta-54333 & N. picea & Limestone & 1930 & $1230 \pm 80$ & 760 \\
Beta-54335 & N.picea & Volcanic & 1924 & $610 \pm 80$ & 140 \\
\hline
\end{tabular}

\section{DISCUSSION AND CONCLUSION}

The apparent ${ }^{14} \mathrm{C}$ ages of marine shells from Hawai' $i$ vary significantly for reasons that are only partially understood. Excluding the anomalous age on $T$. intextus from Pearl Harbor, a weighted mean $\Delta R$ for 13 marine shells of known age is $220 \pm 100$. The scatter sigma of $100 \mathrm{yr}$ is nearly 5 times the sigma derived from the errors reported with the ${ }^{14} \mathrm{C}$ ages, which runs counter to the 24 examples from around the world listed in Stuiver, Pearson and Braziunas (1986), where the scatter sigma is, on average, $c a .10 \%$ greater than the average ${ }^{14} \mathrm{C}$ age sigma.

One factor in this relatively great variation is the influence of old carbon from Pleistocene limestone, which increases the apparent age of marine shells up to $620 \mathrm{yr}$. The weighted mean $\Delta R$ for the three shells from the Pleistocene limestone coast is $690 \pm 90$. The relatively low discharge of freshwater and the free circulation of seawater along the coast of the 'Ewa Plain suggest that old carbon from the limestone makes its way into the shells of animals that ingest it, either indirectly from the algae that they eat, or directly by dissolving and scraping the limestone as they browse. The relatively young apparent age of the $C$. caputserpentis shell, when compared to $N$. picea and $C$. 
exarata shells from the 'Ewa coast, might be due to differences in the diets of the gastropods, or to differences in their habitats. The shallow-water offshore habitat of $C$. caputserpentis is likely to include Holocene reef and reef detritis in addition to Pleistocene limestone.

The effects of factors other than local seashore geology can be seen in the large standard deviation of a pooled $\Delta R$ value for shells from volcanic coasts; a weighted mean $\Delta R$ for 10 shells (excluding L-576D for its unlikely date, and assuming from the apparent age of L-576J that it derived from a volcanic coast) is $110 \pm 80$. Stuiver and Braziunas (1993) note instances of regional and temporal variability in the apparent age of the ocean reservoir due to differences in upwelling and the influence of carbon transported in rivers. Both sources of variability could be active in Hawai'i, where interspecific differences in the uptake of carbon from the environment could also be a factor.

Variation in the apparent ages of Hawaiian marine shells potentially introduces an unacceptable degree of uncertainty in the calibration of archaeological samples. Identification of significant environmental factors, such as the difference in apparent ages of shells from volcanic and Pleistocene limestone coasts, reduces the error terms for $\Delta R$ estimates. Generalized $\Delta R$ estimates for volcanic and Pleistocene limestone coasts, and a specific estimate for the bivalve, $T$. palatam, should prove useful in certain archaeological situations. Additional dates on marine shells of known age and identification of other sources of variability might further reduce the error terms for $\Delta R$ estimates, thereby increasing the utility of marine shell as a material for dating Hawaiian archaeological sites.

\section{ACKNOWLEDGMENTS}

Funding was made available by the Historic Preservation Division, Department of Land and Natural Resources, State of Hawaii. Marine shells from Bishop Museum collections were kindly made available by R. Cowie and R. Kawamoto. T. Braziunas and J. S. Athens offered useful comments on an earlier draft.

\section{GeOLOGICAL SAMPLES}

O'ahu Island

Beta-54331/CAMS-3217. Barbers Point

$980 \pm 80$

Cypraea caputserpentis Linnaeus, BPBM 62407 collected 1915 by W. A. Bryan and E. L. Bryan, B. P. Bishop Museum.

Comment: $C f$. Beta-54334, below.

Beta-54332/CAMS-3218. Barbers Point

$1270 \pm 80$

Cellana exarata (Reeve), BPBM 64557 collected 1914 by W. A. B. and E. L. B.

Comment: $C f$. Beta-54336, below.

Beta-54333/CAMS-3219. Kualakai

$1230 \pm 80$

Nerita picea (Recluz), BPBM 195632 bought 1930 at Honolulu fish market by J. S. Emerson, private collector.

Comment: $C f$. Beta-54335, below. 


\section{Hawai'i Island}

Beta-54334/CAMS-3220. Kaulana

$730 \pm 80$

Cypraea caputserpentis Linnaeus, BPBM 197121 collected 1923 by T. T. Dranga, private collector. Comment: $C f$. Beta-54331, above.

Beta-54335/CAMS-3221. Kea'au $610 \pm 80$

Nerita picea (Recluz), BPBM 198771 collected 1924 by L. A. Thurston and T. T. D., private collectors.

Comment: $C f$. Beta-54333, above.

Beta-54336/CAMS-3222. Kaulana

$740 \pm 100$

Cellana exarata (Reeve), BPBM 198945 collected 1923 by L. A. T. and T. T. D.

Comment: $C f$. Beta-54332, above.

\section{REFERENCES}

Athens, J. S. 1985 Prehistoric Investigations at an Inland Site on the Leeward Slopes of Central Molokai. Honolulu, Privately published: $117 \mathrm{p}$.

Beggerly, P. E. P. (ms.) 1990 Kahana Valley, Hawai i: A Geomorphic Artifact: A Study of the Interrelationships Among Geomorphic Structures, Natural Processes, and Ancient Hawaiian Technology, Land Use, and Settlement Patterns: Ph.D. dissertation, University of Hawaii, Honolulu.

Broecker, W. S. and Olson, E. A. 1961 Lamont radiocarbon measurements VIII. Radiocarbon 3: 176-204.

Davis, B. D. (ms.) 1990 Human Settlement in Pristine Insular Environments: A Hawaiian Case Study from Barbers Point, Southwestern Oahu: Ph.D. dissertation, University of Hawaii, Honolulu.

Emory, K. P. and Sinoto, Y. H. 1969 Age of sites in the South Point area, Ka u, Hawaii. Pacific Anthropological Records 8. Honolulu, Department of Anthropology, Bernice P. Bishop Museum: 17 p.

Holcomb, R. T. 1987 Eruptive history and long-term behavior of Kilauea volcano. In Decker, R. W., Wright, T. L. and Stauffer, P. H., eds., Volcanism in Hawaii. Denver, Colorado, U.S. Geological Survey: 261-350.

Kay, E. A. 1979 Hawaiian marine shells. Bernice $P$. Bishop Museum Special Publication 64(4). Honolulu, Bishop Museum Press: 653 p.
Lockwood, J. P., Lipman, P. W., Petersen, L. D. and Warshauer, F. R. 1988 Generalized ages of surface lava flows of Mauna Loa Volcano, Hawaii. U.S. Geological Survey Miscellaneous Investigations Series Map I-1908.

Macdonald, G. A. and Abbott, A. T. 1970 Volcanoes in the Sea: The Geology of Hawaii. Honolulu, University of Hawaii Press: 441 p.

Stearns, H. T. and Vaksvik, K. N. 1935 Geology and ground-water resources of the island of Oahu, Hawaii. Division of Hydrography Bulletin 1. Spreckelsville, Maui and Honolulu, Territory of Hawaii: 479 p.

Stuiver, M. and Braziunas, T. F. 1993 Modeling atmospheric ${ }^{14} \mathrm{C}$ influences and ${ }^{14} \mathrm{C}$ ages of marine samples to 10,000 BC. In Stuiver, M., Long, A. and Kra, R. S., eds., Calibration 1993. Radiocarbon 35(1): 137-189.

Stuiver, M., Pearson, G. W. and Braziunas, T. 1986 Radiocarbon age calibration of marine samples back to $9000 \mathrm{cal}$ BP. In Stuiver, M. and Kra, R. S., eds., Proceedings of the 12 th International ${ }^{14} \mathrm{C}$ Conference. Radiocarbon 28(2B): 980-1021.

Taylor, R. E. 1987 Radiocarbon Dating: An Archaeological Perspective. Orlando, Florida, Academic Press: $212 \mathrm{p}$. 